Revista Iberoamericana. Vol. LXII, Núm. 175, Abril-Junio 1996; 351-366

\title{
DE VIAJE CON LOS MODERNISTAS ${ }^{1}$
}

\author{
POR \\ MiHAI GRÜNFELd \\ Vassar College
}

La cultura extranjera, y especialmente la herencia grecolatina, ocupa una posición central en el aprendizaje y en la autodefinición del artista modernista latinoamericano. Aunque su aprendizaje estético se efectúa en América Latina, el viaje al extranjero especialmente a Europa - tiene el valor simbólico de una consagración oficial. Este viaje le concede un aura, cierto nimbo que lo separa de la gente ordinaria o de otros artistas porque viajar al extranjero durante la época modernista latinoamericana, fines del siglo XIX y comienzos del XX, representa todavía un hecho raro, al alcance de pocos - generalmente una minoría acaudalada - pero deseado, admirado y envidiado por muchos.

Los países extranjeros pero también lo alejado temporal y espacialmente, o sencillamente lo ajeno, desempeñan un papel estético importantísimo en la poesía modernista. Rodeado de este aura exótico que la distancia, el deseo y la imaginación le confiere, lo lejano está colocado paradójicamente en el centro de la preocupación del artista modernista. Aunque sólo pocos pueden viajar físicamente al extranjero, casi todos participan de una mitología romántica de lo lejano y exótico $\mathrm{y}$, de una manera mediatizada, son viajeros en estas realidades distantes y culturas extranjeras de las que se apoderan interpretándolas y adaptándolas según sus necesidades. En este trabajo nos interesa estudiar cómo se manifiesta en la poesía modernista latinoamericana este viajar, generalmente mediatizado, por las culturas extranjeras. Nos interesa ver tanto su razón de ser como la manera en que lo exótico y lo extranjero participan en la poesía modernista.

En "El caracol y la sirena" Octavio Paz describe el movimiento modernista latinoamericano como una voluntad de situarse en un ahora universal, una voluntad de encontrar el estilo de la época. ${ }^{2}$ Esta definición podría explicar el deseo de los modernistas de viajar al extranjero y de describirlo - aun cuando no lo hayan visto-si entendemos su voluntad de situarse en el ahora primero, como el deseo pragmático de integrarse a un centro

\footnotetext{
${ }^{1}$ Este artículo es el primero de una serie de trabajos que examina el tema del viaje en la literatura latinoamericana.

2 "Se ha dicho que el modernismo fue una evasión de la realidad americana. Más cierto sería decir que fue una fuga de la actualidad local —qua era, a sus ojos, un anacronismo en busca de una actualidad universal, la única y verdadera actualidad. En labios de Rubén Darío y sus amigos, modernidad y cosmopolitismo eran términos sinónimos. No fueron antiamericanos; querían una América contemporánea de París y Londres" (Paz 19).
} 
económico y político desarrollado alrededor de los países de la Europa occidental, especialmente Francia, y segundo, como el deseo de integración cultural con el mismo centro, deseo que se realiza estéticamente en América Latina mediante un estilo literario sincrético en el que el interés por lo exótico ocupa un lugar importante. Examinemos en la primera parte de este trabajo el deseo de integración económica a Europa y en la segunda parte veremos la manifestación estética de este mismo anhelo.

\section{EL ESCRITOR MODERNISTA Y LA SOCIEDAD}

Si caracterizamos la posición de Latinoamérica con respecto a Europa durante la época modernista notamos su marginación tanto económica como cultural, situación que implica una desigualdad entre los dos continentes y generalmente un deseo de integración de la parte periférica al centro. Françoise Perus caracteriza esta situación económica durante la época modernista latinoamericana, 1880-1910, como un "período de implantación del modo de producción capitalista en escala continental". Ella destaca un "desfase" o "retraso" entre Europa y Latinoamérica, desfase que coloca a este continente en "una situación de subordinación que convertirá a las formaciones sociales latinoamericanas en sociedades neocoloniales" (Perus 47). Económicamente encontramos en Latinoamérica una situación típicamente neocolonial caracterizada por el desarrollo de industrias especializadas principalmente en la producción y exportación de materias primas, a la vez que muchas de las necesidades internas se abastecen con productos de importación desde los centros industriales extranjeros. Dentro de este sistema neocolonial notamos sin embargo un aumento continuo de la cantidad de inversiones extranjeras y de materias primas producidas en Latinoamérica, lo cual representa una integración económica progresiva - claro que limitada por la posición periférica del continente latinoamericano- al mercado mundial capitalista específico de aquella época.

La situación cultural es homóloga a lo que destacamos en el campo económico. Según Ángel Rama, en el campo de la cultura tampoco percibimos una integración mutua de valores equiparables. Al contrario, en la relación cultural entre Latinoamérica y países como Francia, Alemania, Italia o Inglaterra sigue vigente una situación neocolonial que nos recuerda la antigua relación de América Latina con España, donde el valor del producto colonial es automáticamente menor al de la metrópolis. ${ }^{3}$ En términos estéticos, esta desvalorización relativa de la creación artística se podría explicar mediante el concepto del aura en la obra de arte, que Benjamin define como un fenómeno de distancia, de singularidad y de autenticidad, cuyo correlato en el receptor sería la actitud de reverencia también

\footnotetext{
3 “Acababan de ponerse en íntimo contacto las grandes potencias económicas en pleno desarrollo industrializador con las comarcas marginadas, demoradas en estructuras artesanales y semifeudales. El cotejo de valores debía producirse fatalmente; el afán de integrarse y equipararse a los niveles de cultura y holgura económica de los europeos se produjo como era previsible; la desvalorización de los productos nativos respecto de los productos extranjeros fue una de las consecuencias primeras, en varios sentidos explicable; la desvalorización de la creación artística tradicional del continente respecto de los productos de más afinada elaboración originarios de Europa fue otra" ( Rama 112113).
} 
encontrada en el fenómeno del rito o del culto. La intensidad del aura de un objeto o de una obra de arte es proporcional a su alejamiento temporal y especial del receptor. ${ }^{4}$ La desvalorización del producto económico y cultural de la periferia, o sea, su pérdida de aura por ser un producto de procedencia local, coincide con la extravalorización del producto de un centro alejado, que adquiere este valor extra de singularidad y autenticidad. Todo lo que procede del centro europeo, de sus ciudades, su gente, está rodeado de este aura, de este nimbo producido y protegido por la distancia, y que consigue el valor de culto, siendo deseable y mejor que el producto de la periferia.

El desarrollo del capitalismo en América Latina significa la aparición en la sociedad finisecular de una creciente clase media, una nueva burguesía radicada especialmente en las grandes ciudades del continente. La especialización y la profesionalización del trabajo, típica de la sociedad capitalista, alcanza también al artista latinoamericano. Éste se encuentra en una posición inestable y de transición entre el mundo de la oligarquía dominante y el de la nueva burguesía. Generalmente no pertenece al grupo detentor del poder. Según Jean Franco, un gran número de poetas modernistas acaba de perder su alta situación en la sociedad a causa del reciente desarrollo capitalista. ${ }^{5}$ En otros casos, como el de Darío por ejemplo, los escritores nunca pertenecieron a este grupo acaudalado y tuvieron que ganarse su existencia trabajando. Al mismo tiempo el sistema de mecenazgos y patrocinios que durante siglos les permitió compartir los privilegios de la aristocracia terrateniente se está debilitando. En un reciente mundo capitalista entonces, en el que los conocimientos técnicos adquieren cada vez más importancia, la función social del artista y su posición social disminuyen considerablemente. En la vida política del Estado los escritores, los sabios asesores intelectuales del ayer, se necesitan cada vez menos. Los expertos de toda índole ocupan esa función. Ocurre entonces un proceso de profesionalización del artista, proceso que intenta contrarrestar su situación marginal cada vez más inestable, y que se realiza de varias maneras. Un número cada vez mayor de artistas desempeñan trabajos periodísticos. Paralelamente con esta profesión encontramos también la de un especialista estético, el bohemio o el artista encerrado en su torre de marfil. Concomitantemente, el quehacer artístico mismo se profesionaliza con la creación, por ejemplo, de un gran número de revistas y de premios literarios. Todo esto representa una lenta redefinición de la función del artista en la sociedad, quien pasa por un proceso de independización profesional.

Junto con el cambio del papel social del escritor, va cambiando poco a poco la función misma de su producto artístico. ${ }^{6} \mathrm{El}$ arte llega a definirse esencialmente en términos de su

\footnotetext{
${ }^{4}$ Ver el artículo apuntado en la bibliografía de Walter Benjamin.

${ }^{5} \mathrm{La}$ rueda de la fortuna giraba erráticamente y en su curso dejaba en la ruina a múltiples familias. El colombiano José Asunción Silva pasó parte de su vida adulta tratando de poner a flote los negocios de su familia, arruinada durante la guerra civil. Los padres de Leopoldo Lugones se vieron forzados a abandonar la hacienda familiar y a instalarse en Córdoba después de atravesar por graves dificultades financieras. A la edad de veinte años, Julio Herrera y Reissig había visto a su familia perder fortuna e influencia política. La familia de Julián del Casal se vio precisada a abandonar su pequeño ingenio azucarero debido al desarrollo en Cuba de las grandes empresas competitivas" (Franco 27-28).

${ }^{6}$ Ángel Rama define este cambio en el campo de la poesía así: "Desapareció la tarea pedagógica que nos había dado odas sobre las ventajas de la vacuna y sobre las reglas de comercio-; desapareció
} 
excelencia artística, o sea, de su función estética, y el artista es el especialista, el conocedor máximo de esa rama de la realidad. El artista se esfuerza por ser, si no un líder de la sociedad o su asesor directo, por lo menos un líder cultural, experto en la estética y en el conocimiento de la realidad interna, del mundo de los sentidos y de las emociones. En otras palabras, el artista llega a representarse como un ser especial, aparte, sensible y sensitivo, y por lo menos en lo concerniente al arte, el especialista máximo.

Paralelo con el empeño de mejorar su situación de profesional inmerso en una sociedad burguesa, el escritor muestra su identificación con la aristocracia, al dirigir mucho de su trabajo estético al grupo detentor del poder, grupo que forma su principal público consumidor. Es una situación ambigua y tal vez paradójica, que delata el proceso de transición del papel del escritor en la sociedad y su resistencia frente al cambio que está ocurriendo. Muchos modernistas pierden pues no sólo su posición dentro de la aristocracia sino también el apoyo sustancial que ésta le ofrecía. Al mismo tiempo la especialización de la escritura misma al enfocar cada vez más el lado estético requiere un receptor especialista, conocedor de la materia estética. Tradicionalmente este público fue la clase aristocrática, esta minoría que, además de los escritores mismos, es la única que dispone del interés, el tiempo y el dinero necesario para desarrollar el lado estético de su personalidad. Aunque su situación económica lo excluye de esta posición, el escritor llega a percibirse cada vez más como una aristocracia del pensamiento y del arte. Según el libro de Perus, hasta en su trabajo periodístico, que de hecho se dirige a la clase media, el escritor se caracteriza por un trabajo de rasgos más bien estéticos que sensacionalistas y que cumple irónicamente la función de diferenciarlo de su público burgués y de identificarlo con la aristocracia detentora del poder. Esta identificación es muy aparente por ejemplo en la Autobiografia de Rubén Darío, en la que el poeta enfoca de una manera excesivamente detallada su vida social a despecho de su realidad intima o de sus ideas estéticas y filosóficas. La lectura de este trabajo resulta muy desilusionante porque el poeta se complace en darnos una lista pormenorizada de todas las personas importantes con quien tuvo el más mínimo contacto. Es una lista completa de sus encuentros sociales, en la que cada persona importante, figuras políticas de la aristocracia o del mundo artístico, lleva una breve caracterización junto con la descripción de la manera en que se relacionó con el poeta. Al escribir su autobiografía Darío se fija pues, casi exclusivamente en el desarrollo y la importancia de su persona social, identificada especialmente con la aristocracia detentora del poder y con el mundo estético que ella comparte con los artistas.

la tarea de ilustración que describía la nueva geografia americana con un esfuerzo de apropiación intelectual del contorno; la tarea histórica que estaba destinada a intensificar la vinculación con un pasado nacional para generar la idea de nación en una masa recién descolonizada; la tarea religiosa que predicaba con ejemplos poéticos las verdades del catolicismo o que en los grandes poemas (Tabaré) se alzabaa la explicación metafísica del hombre americano; latarea jurídica de adoctrinamiento en los principios del Estado, y desde luego la contribución cotidiana de la poesía a la vida íntima de los hombres, fortaleciendo en ellos el concepto de familia - poemas a los nacimientos, las bodas, los duelos, los triunfos-, etcétera. Lo que el poeta abandona es la multiplicidad de funciones que justificaban y explicaban, más allá de la excelencia artística posible de sus obras, su lugar en la vida social y su papel histórico dentro de una determinada comunidad tradicional” (Rama 45). 
Desde el punto de vista temático notamos esta misma identificación del escritor con la aristocracia. La escritura modernista representa un aislamiento del medio ambiente cotidiano en que vive el artista. Ella reproduce temáticamente un mundo estético de lo bello y lo ideal, un mundo exótico y lejano. El artista desempeña un papel central en este mundo estético suyo, en este universo aristocrático elaborado sobre la cultura grecolatina y una multitud de elementos extranjeros y exóticos. Los valores estéticos del artista rigen en esta creación que es un mundo aristocrático - hasta cierto punto paralelo con la realidad circundante - pero en cuyo ápice no se encuentra la verdadera aristocracia sino el artista, experto por definición de su propio mundo.

A través de su praxis, de esta escritura estéticamente especializada, el escritor trata de forjarse un lugar especial en la sociedad. Una de las maneras por la cual se realiza este proceso es la participación del escritor en la cultura extranjera por medio de un viaje real o de la descripción imaginaria del mundo extranjero. Los pocos modernistas que logran viajar verdaderamente se dirigen hacia Europa, mientras que un viaje a Africa o al Oriente, como en el caso del mexicano José Juan Tablada, es todavía una rareza. El viaje a Europa, o específicamente a París, representa para el artista latinoamericano un acto simbólico de la integración con un centro económico y cultural. Digo simbólico porque en la mayoría de los casos consiste en un sencillo recorrido, una visita a los lugares turísticos más conocidos. Se trata de una visita estética selectiva a los íconos culturales ya aceptados y reconocidos como parte íntegra de la civilización occidental, según lo explica David Viñas al escribir sobre el viaje modernista en su libro Literatura argentina y realidad política. Como turista, el artista modernista se siente demasiadas veces un extranjero fuera de su ambiente, aun cuando se queda a vivir y trabajar, integrándose en este caso a un grupo marginado de compatriotas y artistas principalmente extranjeros como él. Aunque no resulta ser una integración cultural verdadera, el viaje -que consiste en visitar y vivir en las grandes capitales europeas - le contagia sin embargo al artista con su aura. Para sus compatriotas en la sociedad latinoamericana es una confirmación ritual que trae consigo privilegios especiales concedidos a los viajeros que ahora llegan a ser representantes de la cultura cosmopolita europea.

\section{El VIAJE ESTÉTICO MODERNISTA}

La prosa periodística modernista nos ofrece varios ejemplos de la fascinación que el extranjero, pero especialmente una ciudad como París, ejerce sobre los latinoamericanos. Ésta es la ciudad universal que como un fuerte imán atrae al artista modernista, pidiéndole —en la imaginación de éste- visitarla y conocerla. Pero, no se trata de cualquier París sino de un lado suyo específico. En su artículo "La última ilusión”, Julián del Casal describe esta ciudad así:

Te diré: hay en París dos ciudades, la una execrable y la otra fascinadora para mí. Yo aborrezco el París célebre, rico, sano, burgués y universal; el París que celebra anualmente el 14 de Julio; el París que se exhibe en la Gran Opera, en los martes de la Comedia Francesa o en las avenidas del Bosque de Bolonia; .... el París en fin que atrae millares y millares de seres de distintas razas, de distintas jerarquías y de distintas nacionalidades. Pero yo adoro, en cambio, el París raro, exótico, delicado, sensitivo, brillante y artificial; el París 
que busca sensaciones extrañas en el éter, la morfina y el haschich; ... y el París, por último, que no conocen los extranjeros y de cuya existencia no se dan cuenta tal vez (Casal 228229).

Casal describe, por un lado, la ciudad moderna de comienzos de siglo, un lugar en pleno desarrollo industrial, un centro turístico cosmopolita hacia el cual se encaminan "millares y millares de seres de distintas razas, de distintas jerarquías y de distintas nacionalidades". Éste es el centro burgués que más tarde fascinará a los poetas vanguardistas pero que Casal —encerrado en su singular torre de marfil- aborrece. Es importante notar que a Casal le displacen manifestaciones específicamente exteriores o públicas de la ciudad, como la celebración popular del 14 de Julio en las calles parisienses, las avenidas del Bosque de Bolonia, la Comedia Francesa, manifestaciones populares de una burguesía floreciente la clase social más reciente que desplaza con su prosperidad y comunalidad lo raro y lo excepcional de los modernistas. Y no es que Casal jamás haya visto París. Es desde su propia casa que este poeta sueña con una ciudad "rara, exótica, delicada, sensitiva, brillante y artificial". Éstas son las características generales de un "lugar estético" según las define David Viñas en su libro Literatura argentina y realidad politica. Se trata generalmente de espacios encerrados, refinados, artificiales, como los interiores decadentes de $A$ Robours de Huysmans, o De sobremesa, del colombiano José Asunción Silva. Charles Baudelaire es un ejemplo temprano del proceso de creación de un lugar estético cuando evoca por medio del aroma sensual de los senos de su amada una isla exótica y lejana, con una naturaleza abundante y generosa:

Quand, les deux yeux fermées, en un soir chaud d'automne

Je respire l'odeur de ton sein chaleureux

Je vois se derouler des rivages heureux

Qu'éblouissent les feux d'un soleil monotone.7

Tanto el París de Julián del Casal como la isla tropical de Baudelaire son productos imaginarios, ensoñaciones evocadas en la mente del artista por medio de unos pocos elementos, asociados en la época con un ambiente decadente. Ambas descripciones se caracterizan por la presencia de una sensualidad desbordante, por la pereza y la sexualidad intensificadas muchas veces por el uso de drogas. Casal imagina este modo de vida en un París interior repleto de obras de arte delicadas, perfumes orientales, comidas raras y sensaciones extrañas, mientras que Baudelaire la celebra en una isla exótica de características semejantes; ambos apuntan hacia un modo de vida ideado por los simbolistas franceses, cuya admiración por lo raro y exquisito - dentro de los confines de una sociedad burguesa de consumo- se manifiesta generalmente por objetos e interiores que son capaces de recrear en la imaginación de los poetas un ambiente evocador de lo lejano. La "voluntad de situarse en un ahora universal y encontrar el estilo de la época" significa para un poeta modernista como Casal vivir y admirar lugares exóticos y artificiales creados por su imaginación y calcados en el modelo simbolista francés.

7 "Parfum exotique", en Poesie française. Anthologie critique, 199. 
Cabría tal vez preguntarse en este momento hasta qué punto, en la descripción por ejemplo de París, importa el hecho de que el poeta haya visitado alguna vez esta ciudad y si esta ciudad central, clave e indicio del mundo europeo moderno, aparecería de manera distinta en la obra de artistas que han viajado y trabajado extensamente allí. En su prosa periodística Rubén Darío describe a menudo París, casi siempre de una manera legendaria. Dado que se trata de un trabajo de índole periodístico, este poeta —al contrario de Casalno evita los lugares abiertos haciendo una crónica de la vida parisiense, de los acontecimientos que le llaman la atención y por los cuales el lector marginado latinoamericano tiene una sed inagotable. Pero, a pesar de que en su escritura periodística Darío describe eventos que ocurren en lugares abiertos - como por ejemplo en las calles- la impresión de lo raro y excepcional permea su descripción. Aunque se trata de cosas mundanas, de eventos públicos como la visita de una figura importante, o de un ensayo biográfico sobre un poète maudit, un aura rodea siempre sus descripciones. El propósito que se perfila detrás de este proceso que deforma mitificando - proceso deseado tanto por el escritor como por el lector latinoamericano ávido éste de conocer y de imaginar la vida de la ciudad distante - es el de deslumbrar al crear una realidad casi maravillosa. Veamos como ejemplo lo que Darío percibe en las calles parisienses en una de sus descripciones periodísticas:

He visto más; he visto lo que creía que ya no existía sino en los viejos cuadros, en los viejos grabados: he visto en ciertos barrios de París el antiguo pifferaro y el organillo y la mona vestida de colorines, y la linda italianica, ya casi púber, que danza al son del violín y recoge después en un plato las limosnas de los curiosos. Y existen aún, aunque en menor escala que antes, los saboyanitos de los melodramas y de las romanzas. Y el horrible mercado de la prostitución pueril, la importación de niñas, por inicuos proxenetas de ambos sexos, que no temen exhibir su especialidad en pleno bulevar (Darío, Obras completas 1271).

En este artículo periodístico, que al parecer nos remite a la realidad parisiense cotidiana, encontramos un proceso selectivo, usado también por Casal al evocar la misma ciudad, proceso por medio del cual se deforma y mitifica la realidad. El lado sórdido de la ciudad de Darío desempeña el mismo papel que lo raro, lo bello y lo excepcional en Casal. El pifferaro, por ejemplo, es una figura pastoril que tocaba una flauta y "en la época del Adviento pasaba a Roma y, ante las imágenes de la Virgen que había en las esquinas, tañía pifanos (pifferi) y zampoñas (zampogne) recogiendo las monedas que les daban los transeúntes y vecinos" (Enciclopedia Universal Ilustrada 820). Esta figura pintoresca de "los viejos cuadros" que toca el organillo está acompañado por "la linda italianica, ya casi púber, que danza al son del violín", la cual es nada menos que la Esmeralda de Notre Dame de Paris, el arquetipo romántico de la persona marginada - exquisita, atractivay misteriosa. "Los saboyanitos de los melodramas y de las romanzas" y "el mercado de la prostitución pueril" se ven como cosas raras, pintorescas e interesantes, rodeadas de un aura que la distancia y su imaginación aumentan considerablemente porque para el lector periférico hispanoamericano pertenecen a una cultura central prestigiosa. Y no es que en América Latina no se encuentra prostitución infantil ofiguras marginales semejantes a las parisienses. Pero "la voluntad de situarse en un ahora universal y encontrar el estilo de la época" acaba por obligar a un escritor-periodista como Darío a esconder o evitar el paralelismo obvio 
entre su situación real de extranjero latinoamericano marginado en el ambiente francés y lo raro y extraño de sus descripciones de la ciudad parisiense. ${ }^{8}$ Todo está cubierto por el velo de la reina Mab, este filtro modernista que consigue deformar la realidad, presentándola bajo la apariencia de un lugar exótico compuesto por un conjunto de elementos preciosistas. La distancia que existe entre el narrador latinoamericano y lo que retrata como una curiosidad elimina cualquier posibilidad de identificación humana con lo descrito, de sentir el horror, la soledad y la alienación de la vida en una gran ciudad moderna. El enfoque de la descripción es desde un "yo" de origen latinoamericano orgulloso de haber visto y experimentado cosas tan extrañas, hecho que contagia al escritor mismo y acaba por crear una homología entre lo excepcional de la vida parisiense y lo de la persona que la describe.

Este proceso es especialmente interesante cuando notamos que para los modernistas latinoamericanos Europa occidental en general y París en particular conjugan los atributos de dos lugares muy diferentes: por una parte son el centro político y cultural moderno que los latinoamericanos visitan constantemente para participar simbólicamente de la modernidad, y por otra, son un lugar exótico que los artistas y periodistas describen cuidadosamente, sirviéndose de la misma retórica exoticista que usa el centro para su propia periferia Africa, el Oriente o América Latina. ${ }^{9}$ París resulta ser el centro económico y cultural por excelencia, y al mismo tiempo es un lugar exótico "raro, delicado, sensitivo, brillante y

${ }^{8}$ Latinoamérica igual que el Oriente representaba lo marginado para la sociedad central francesa, y Darío mismo, al estar en París, se siente como una persona exótica. En el poema "Epístola a la señora de Leopoldo Lugones" dice:

Y me volví a París. Me volví al enemigo

terrible, centro de la neurosis, ombligo

de la locura, foco de todo surmenage

donde hago buenamente mi papel de sauvage

encerrado en mi celda de la rue Marivaux,

confiado sólo en mí y resguardando el yo.

¡Y si lo resguardara, señora, si no fuera

lo que llaman los parisienses una pera!

A mi rincón me llegan a buscar las intrigas,

las pequeñas miserias, las traiciones amigas,

$\mathrm{y}$ las ingratitudes. Mi maldita visión

sentimental del mundo me aprieta el corazón,

y así cualquier tunante me explotará a su gusto

(Darío Obras completas, 1023).

${ }^{9}$ Es interesante notar que Grecia y España también forman parte de este Oriente imaginario. El hecho de que Grecia sea percibida como país oriental se explica tal vez por la ocupación otomana que duró hasta 1829. La literatura romántica inglesa, francesa y alemana sitúan a España en la misma categoría. He aquí por ejemplo la manera de que el escritor francés Alfred de Vigny describe a un español: "Un Espagnol est un homme de l'Orient, c'est un Turc catholique; son sang languit ou bouillonne, il est paresseux ou infatigable; l'indolence le rend esclave; l'ardeur, cruel; immobile dans son ignorance, ingénieux dans sa superstition, il ne veut qu'un libre religieux, au'un maître tyrannique; il obéit à la loi du bûcher, il commande par celle du poignard; il s'endort le soir dans sa misere sanglante, cuvant le fanatisme et rêvant le crime. Qui est-ce là, messieurs? est-ce l'Espagnol ou le Turc? devinez". Alfred de Vigny, Oeuvres completes, vol. III, Cinq-Mars, Paris, Louis Conard, libraire-éditeur, 19141922, 214. Citado en Victor Hugo, Les Orientales (París: Librairie Marcel Didier, 1952) xvii. 
artificial", según lo vimos en la descripciones de Casal y Darío. Sin duda alguna, los modernistas latinoamericanos están conscientes de que su propia realidad es vista desde París como exótica. El París literario le devuelve al escritor latinoamericano modernista, como en un espejo, su imagen exótica. El afán de integrarse a la modernidad, asumiendo una personalidad cosmopolita y considerándose un ciudadano universal - viajero real o imaginario en el espacio, el tiempo, y las culturas lejanas y modernas - representa su deseo de contrarrestar esta imagen de atraso económico y cultural. Es un mecanismo por medio del cual escritores como Darío y Casal huyen de su situación real de marginados, identificándose implícitamente con una visión del centro. La descripción de la ciudad de París - que es el centro- está dirigida a un lector periférico pero los dos se valen de una retórica exoticista centrista que tiene la función de reforzar su identificación con este centro y negar su identidad y situación reales. Al asumir una visión exoticista, los escritores modernistas se sitúan mentalmente en el centro y participan implícitamente en una conquista ideológica. Es una manera indirecta de negar su realidad periférica, tomando parte junto con los otros países "civilizados" en un proceso de ocupación y culturalización que finalmente delata la continuación de su estado culturalmente colonizado.

Por consiguiente, el viaje real a estos países extranjeros parece tener poca relevancia porque no deja huellas significantes ni en la prosa de Darío ni en la de Casal. Los dos se valen del mismo sistema simbolista de evocar un centro alejado y prestigioso por medio de imágenes exóticas, sin describir la verdadera experiencia de un viajero. Mediante esta perspectiva central europea, también asumida tradicionalmente por las clases dirigentes latinoamericanas, los dos participan en un discurso centrista, basado en una ideología colonialista que, en lo estético es reduccionista y estereotipante y recrea un mundo periférico exótico y lejano. Estéticamente, el haber vivido y conocido el centro, el mundo europeo, aumenta la autoridad y autenticidad de la voz del artista, participando así en el proceso de valoración de su posición y estado social de especialista y profesional. ${ }^{10}$

Si dejamos la prosa y examinamos ahora la poesía modernista encontramos que las bases estéticas del viaje se encuentran en un patrón establecido ya por los escritores románticos, quienes tuvieron un gran interés en la evocación de lo exótico y lejano. En el soneto "Cosmopolitismo" Manuel González Prada nos propone un primer patrón del viaje, fundado sobre la tradicional oposición romántica entre la voz poética, un héroe o una persona excepcional, y la sociedad opresiva, abrumadora y estática que lo rodea:

¡Cómo fatiga y cansa, cómo abruma,

el suspirar mirando eternamente

los mismos campos y la misma gente,

los mismos cielos y la misma bruma!

Huir quisiera por la blanca espuma

y a sol lejano calentar mi frente.

¡Oh, si me diera el río su corriente!

¡Oh, si me diera el águila su pluma!

\footnotetext{
${ }^{10}$ Sobre la profesionalización de los modernistas ver Francine Masiello, especialmente "El programa modernista" 31-33.
} 
Yo no seré viajero arrepentido

que, al arribar a playas extranjeras, exhale de sus labios un gemido.

Donde me estrechen generosas manos, donde me arrullen tibias primaveras, allí veré mi patria y mis hermanos (González Prada 53-54).

El poeta resuelve la tensión típicamente romántica entre el héroe y su mundo a través de la huida. La voz poética necesita escaparse de su vida ordinaria y rutina diaria y expresa su anhelo de viajar en busca de una patria más acogedora. En este tipo de poema de viaje lo importante es el deseo de escaparse que el héroe siente y expresa, mientras que la patria o las playas extranjeras hacia las cuales huye la voz poética de González Prada apenas si están definidas. Es un destino lejano y vago, siempre preferible a lo que lo rodea. Lo fundamental para este poeta modernista de tendencia romántica es la necesidad de expresarse a sí mismo, de expresar sus propios sentimientos que tienen como base una vaga noción de cosmopolitismo y una identidad cosmopolita eminentemente ficticia que la voz asume.

Un patrón simbolista bastante común -distinto del de Manuel González Prada—de expresar el estado de ánimo impregnado del deseo de escaparse de un mundo pequeño burgués, monótono y aburrido es mediante la transferencia de los sentimientos y emociones del poeta sobre el objeto de su descripción. El "exotismo romántico" de Theophile Gautier es un modelo temprano de este proceso de transferencia:

Chez moi, déclarait-il devant les Goncourt le 23 novembre $1863, \ldots$ ç'a étél'emmer[dement] ... de mon temps qui m'a fait chercher une espèce de dépaysement. - Oui, oui, vous avez la nostalgic de l'obélisque, lui disions-nous. - C'est cela, et c'est ce que Sainte-Beuve ne saisit pas. II ne se rend pas compte que nous sommes tous quatre des malades ... Ce qui nous distingues, c'est l'exotisme. II y a deux sens de l'exotique: le premier vous donne le goût de l'exotique dans l'espace, le goût de l'Amérique, le goût des femmes jaunes, vertes, etc. Le goût plus raffiné, une corruption plus supreme, c'est ce goût de l'exotisme à travers les temps: par exemple, Flaubert serait heureux de forniquer à Carthage; vous voudriez la Parabère; moi, rien ne m'exciterait comme une momie (Citado en Joudra 13).

Una de las principales atracciones de Gautier - y esto no es distinto de muchos artistas de su generación - se manifiesta en el deseo de poseer de una manera mediatizada lo exótico, al, por ejemplo, hacer el amor con una mujer exótica, extranjera, representante de un país lejano. Rana Kabbani demuestra convincentemente que tanto las narraciones europeas de viajes como la pintura decimonónica tienden a describir el Oriente como una región de sensualidad lasciva y de violencia inherente:

Europe was charmed by an Orient that shimmered with possibilities, that promised a sexual space, a voyage away form the self, an escape from the dictates of the bourgeois morality of the metropolis. The European reacted to the encounter as a man might react to a woman, by manifesting strong attraction or strong repulsion ... The European was led into the East by sexuality, by the embodiment of it in a woman or a young boy. He entered an imaginary harem when entering the metaphor of the Orient, weighed down by inexpressible longings. 
His century had pushed women into rigid roles: the leisured middle-class wife who was suposedly dormant sexually, the domestic sevant whom labour unsexed, and the prostitute who was burdened with all that the wife was protected from (Kabanni 67).

El proceso de transferencia psicológica de los sentimientos del autor, proceso mediante el cual una sociedad burguesa reprimida proyecta las prohibiciones morales de su ambiente sobre los países lejanos, resulta en una visión exótica, llena de sexualidad y violencia. Es absolutamente esencial recordar en este lugar la oposición centro-periferia sobre la cual se basa esta creación de lo exótico. La existencia del así llamado mundo "civilizado" con todas sus restricciones sobre el cuerpo biológico hace necesario esta transferencia, o sea la creación imaginaria de un mundo misterioso, salvaje y sexual, de un mundo sobre el cual se puede proyectar todo lo prohibido. Una de sus consecuencias más obvias es la atracción que este mundo periférico ejerce sobre las personas del centro, pero paralelamente notamos la necesidad de conquistar, dominar y "civilizar" lo exótico, de destruir lo que tanto atrae. Ésta es una de las causas psicológicas que explican la ulterior colonización llevado a cabo por las armas de un ejército o las ideas de una iglesia.

En la producción modernista latinoamericana - en el París exótico de Darío o en el París refinado de Casal- hemos notado este mismo proceso de transferencia que destaca el elemento sexual asociado con lo lejano exótico. En la poesía modernista del boliviano Ricardo Jaimes Freyre encontramos además el lado violento de que habla Kabbani. Como Baudelaire, en su conocido poemario Les Fleurs du Mal, Jaimes Freyre desarrolla las posibilidades estéticas del mal en el universo extraño de la mitología escandinava. Por ejemplo, en el poema "El canto del mal" coexisten lado a lado lo bueno y lo malo, para formar juntos la unidad de la experiencia humana.

Canta Lok en la obscura región desolada, y hay vapores de sangre en el canto de Lok. El Pastor apacienta su enorme rebaño de hielo, que obedece, - gigantes que tiemblan, -la voz del Pastor. Canta Lok a los vientos helados que pasan, y hay vapores de sangre en el canto de Lok (Jaimes Freyre 25-26).

Jaimes Freyre describe en este poema simbolista una región mítica violenta, sombría, llena de terror y de muerte, situada en un norte escandinavo regido por un dios punitivo. Pero a pesar de esta ambientación aparentemente negativas el mundo mitológico del poema tiene el mismo misterioso interés y atractivo que el París de Darío o la isla exótica de Baudelaire.

La poesía modernista de José Juan Tablada, viajero prolífico que vivió bastante tiempo en el Oriente, ofrece otro patrón romántico de describir el viaje exótico. Además de sus hai kus y de los poemas "ideogramas" basados en modelos orientales, Tablada escribió mucho sobre los países que conoció personalmente en sus viajes. He aquí algunos versos del poema "Japón": 


\author{
¡Jardín que un raro kaleidoscopio \\ Borda en mi mente con sus cristales! \\ Tus teogonías me han exaltado \\ $\mathrm{Y}$ amo ferviente tus glorias todas; \\ ¡Yo soy el siervo de tu Mikado! \\ ¡Yo soy el bonzo de tus pagodas! \\ Tú eres el opio que narcotiza, \\ $\mathrm{Y}$ al ver que aduermes todas mis penas \\ Mi sangre - roja sacerdotisa- \\ Tus alabanzas canta en mis venas (Tablada 122).
}

Esta descripción del Japón, país exótico que pocos hispanoamericanos podían haber visitado para aquel entonces, se caracteriza por una serie de elementos emblemáticos evocadores de un país lejano y generalmente desconocido. Falta en esta descripción la gama emotiva normal, característica de toda experiencia de viaje en el extranjero. Tampoco hay aquí elementos que no sean puro elogio o alabanza, que no demuestren la admiración y veneración absoluta que el poeta siente por Japón. Los detalles que conforman este retrato poético no describen sino que refieren a una imagen compuesta de lugares comunes y estereotipos decantados como el opio, los jardínes, el Mikado, las pagodas y el Fusiyama. Estos elementos recrean un Japón público dolorosamente simplista, dado que fue hecha por una persona que realmente vivió en el Japón y lo conoció personalmente.

Un posible modelo europeo de esta descripción se encuentra en la poesía romántica de Víctor Hugo. Por ejemplo, en el poema "Le feu du ciel" de su poemario Les Orientales, Hugo, quien nunca habla viajado a Africa, describe varios lugares exóticos como Egipto, las ciudades bíblicas de Babel, Sodoma y Gomorra, el desierto, y unas tribus primitivas africanas. La visión exótica de este escritor romántico francés del siglo XIX se compone de una serie de lugares comunes, convencionales y estereotípicos, muchas veces efectivamente inventados. Su intención no es la descripción exacta del país lejano sino una evocación mediante imágenes bien conocidas que refuerzan lo estereotípico en vez de eliminarlo.

En la tradición romántica a la cual los modernistas latinoamericanos se adhieren, hemos notado que González Prada enfoca los sentimientos del poeta, especialmente su deseo de escapar, que Darío y Casal proponen un París exótico y sexual, que Jaimes Freyre describe un mundo escandinavo regido por la violencia y el mal, y finalmente que Tablada se refiere a un viaje al Oriente específico, reconocible geográfica e históricamente, pero construido sobre un legado común de imágenes estereotipantes que el Occidente ha desarrollado a través de un lento proceso de coloniaje. ${ }^{11}$

Los parnasianos franceses evocan muchas veces una realidad lejana y distante por medio de la descripción estática de una obra de arte pictórica. Modernistas como Casal imitan este estilo en el soneto "Elena"(Nieve 1892) por ejemplo - una pintura de Gustave

${ }^{11}$ En Orientalism Edward Said muestra la vinculación que existe entre un proceso imaginativo de creación del Oriente, proceso basado en su totalidad en estereotipos deformantes, y un proceso político de conquista y colonización del mismo territorio. 
Moreau reproducida en su época en la revista cultural La Habana elegante. El poeta cubano sigue el estilo parnasiano de la época, al dibujar de una manera fría, distante, y poco emocional, una escena pictórica -Elena mirando los escombros provocados por la guerra de Troya- que pertenece a la historia y mitología griegas. A pesar de haberse tratado de una guerra sangrienta y de extensa duración, el retrato de Casal, igual que la pintura de Moreau, se caracteriza por su estatismo refinado y escultórico, evidente en una Elena, que contempla impávida e indiferente, los escombros que la rodean. En el arte modernista latinoamericano, igual que en el de los parnasianistas franceses, el mundo clásico tiene un alto prestigio y un valor especial. Para Casal, su recreación poética es paralela a la evocación de un París ensoñado que nunca llegó a visitar, pero cuya descripción en el artículo "La última ilusión" ya hemos examinado.

Otra manera de viajar hacia lugares prestigiosos del pasado, lugares que reemplazan un presente autóctono desprestigiado, lo encontramos en el poema "Caupolicán". Darío describe en este poema una ocurrencia histórico-mitológica amerindia que caracteriza en términos de la mitología grecolatina. En un poema como "A Margarita Debayle" el mismo Darío nos transporta hacia un país enteramente fantástico, un cuento de reyes y princesas que tiene su parentesco en el campo folklórico, campo que ganó mucho prestigio entre los escritores románticos. Este poema es de algún modo emblemático de todo el grupo que venimos enumerando porque el poeta ni siquiera pretende describir o referirse a un país real. Se trata abiertamente del mundo de las hadas, un producto de la imaginación pura, constituido por un palacio de diamante y poblado por personajes y elementos fantásticos como reyes y princesas. Es un poema que intenta recrear una realidad coherente, no describiéndola en detalles sino imaginándola, aludiendo y evocándola con cierto tipo de símbolos culturales emblemáticos. El viajar a estos países es un acto de imaginación tanto para el poeta como para el lector, un escape en una creación éticamente monocromática un mundo bello, un mundo malo, un mundo sexual o un mundo violento- siempre más atractiva que la realidad.

\section{Conclusiones}

Al resumir entonces el viaje al extranjero durante la época modernista, hemos visto la situación social precaria del artista latinoamericano en un mundo cambiante. Su papel de escritor se está transformando. Aunque históricamente se identifica con la aristocracia, con los detentores del poder, su reciente situación social no lo coloca automáticamente en la misma clase. Ha perdido los privilegios de que gozaba en el sistema anterior. Como resultado, unos artistas se aislan y viven una vida bohemia en que siguen identificándose política y estéticamente con la aristocracia mientras que otros tratan de profesionalizar su quehacer artístico intentando valorar su papel social y forjarse una mejor situación mediante su arte. Dada la situación de marginación económica y social de América Latina con respecto a Europa, que resulta en la devaluación de lo autóctono y en la supervaloración de lo extranjero, la participación en la realidad central europea, en la cultura extranjera mediante un viaje real o mediatizado resulta ser una praxis muy importante para el escritor latinoamericano. 
Al examinar la manera en que Casal y Darío describen el viaje hacia lo lejano, en este caso la ciudad de París, hemos notado los preceptos heredados de la escuela simbolista basada especialmente en la evocación de una realidad exótica, decadente, sensual, rodeada de un aura de lo raro y excepcional. En esta composición falta por completo la descripción de la experiencia cotidiana de viajar en el extranjeroy, a la vez, falta cualquier identificación humana con la alienación que caracteriza la vida en la gran ciudad moderna. En estos textos que describen la vida parisiense notamos un paralelismo interesante entre la descripción del centro como un lugar exótico con muchas características marginales, y la propia marginalidad latinoamericana en relación con ese centro. Hemos visto que por medio de una operación de transferencia, lo lejano aparece como un lugar imbuido de misterio, de sexualidad y de violencia, esto último especialmente en el caso de la obra de Jaimes Freyre. También hemos visto que en la poesía modernista de origen romántica los poetas evocan y sugieren el extranjero por medio de símbolos, de elementos emblemáticos y lugares comunes. La descripción del Oriente de Tablada nos ha servido de modelo aquí. Finalmente, de los parnasianos franceses, los modernistas toman el interés en viajar a lugares prestigiosos del pasado, de reconstruirlos por medio de la fantasía e imaginación, lo cual apunta hacia el carácter netamente lírico y ficticio de la descripción del extranjero, más emblema que realidad. Todo esto nos hace pensar que la poesía modernista pasa por un filtro riguroso, una auto-censura del poeta que no le permite describir lo ordinario y lo cotidiano latinoamericano, puesto que paradójicamente, esto no pertenece a un "ahora universal", a "un estilo [poético] de la época" sino a una realidad latinoamericana considerada más bien atemporal. En el prólogo de su Prosas profanas Darío explica lo que para él significa ser moderno, destacando esta oposición entre la actualidad latinoamericana y el material que sí pertenece temáticamente al estilo de la época:

\begin{abstract}
¿Hay en mi sangre alguna gota de sangre de África, o de indio chorotega o nagrandano? Pudiera ser, a despecho de mis manos de marqués; mas he aquí que veréis en mis versos princesas, reyes, cosas imperiales, visiones de países lejanos o imposibles; ¡qué queréis!, yo detesto la vida y el tiempo en que me tocó nacer; y a un presidente de República, no podré saludarle en el idioma en que te cantaría a ti, ¡oh Halagabal!, de cuya corte-oro, seda, mármol-me acuerdo en sueño ...

Si hay poesía en nuestra América, ella está en las cosas viejas: en Palenke, y Utatlán, en el indio legendario y el inca sensual y fino, y en el gran Moctezuma de la silla de oro. Lo demás es tuyo, demócrata Walt Whitman (Darío, Poesía 180).
\end{abstract}

Todas estas evocaciones de princesas, reyes, países lejanos y tiempos legendarios están rodeadas por el aura de la distancia especial y temporal. Un poema de González Prada nos ha facilitado definir unas características románticas de la poesía de viaje modernista, como por ejemplo el deseo de huir hacia una realidad lejana y a la vez la preponderancia de los sentimientos y emociones del poeta. La poesía que en la época modernista quiere recrear lo bello se identifica con estos elementos exóticos y el poeta es un ciudadano universal en la medida en que es un viajero participante de estas realidades lejanas. El poeta se percibe como un ser cosmopolita, una persona especial que tiene la función de describirnos estas realidades distantes, estos países exóticos, alejados temporal y espacialmente. Pero también hemos visto que en la medida en que el poeta asume el discurso exoticista del centro su colonización cultural queda intacta. 
Si recordamos ahora nuestro punto de partida en que Octavio Paz define el movimiento modernista como una voluntad de situarse en un ahora universal, una voluntad de encontrar el estilo de la época, nos damos cuenta de que el "ahora universal" es en realidad una figura retórica, un oximoron imposible. El "ahora universal" o el "estilo de la época" con que los modernistas quieren identificarse es más bien una creación sincrética imaginaria. El estilo de la época representa una combinación de varios estilos -romántico, simbolista y parnasiano- que han existido en Europa en distintos momentos históricos. La conciencia universal cosmopolita del escritor latinoamericano y el tiempo "moderno" en que éste desea vivir es un orden compuesto e imaginado en una poesía de viaje bella y misteriosa, que refleja su propia marginación con respecto a un mundo central burgués europeo en pleno desarrollo.

\section{OBRAS CITADAS}

Baudelaire, Charles. Les Fleurs du Mal. París: Librairie Didier, 1961.

Benjamin, Walter. "The Work of Art in the Age of Mechanical Reproduction". Illuminations (New York: Harcourt, Brace and World Inc., 1955): 219-253.

Casal, Julián del. "La última ilusión". Prosas (Tomo I, Biblioteca Básica de Autores Cubanos. La Habana: Edición del Centenario, Consejo Nacional de Cultura, 1963): 228-229.

Poesías. Edición del Centenario. Biblioteca Casa de Autores Cubanos. La Habana: Consejo Nacional de Cultura, 1963.

Darío, Rubén. Obras completas. 5 vols. Madrid: Afrodisio Aguado, S.A.,1953.

Poesía. Prólogo Ángel Rama. Edición Ernesto Mejía Sánchez. Cron. Julio Valle-

Castallo. Caracas: Biblioteca Ayacucho, 1977.

Enciclopedia Universal llustrada. Barcelona: Hijos de J. Espasa Editores, 1921.

Franco, Jean. La cultura moderna en América Latina. Trad. Sergio Pitol. México: Joaquín Mortiz, 1971.

González Prada, Manuel. Minúsculas ( $4^{\mathrm{a}}$ ed.) Adoración $1^{\mathrm{a}}$ ed. Pról. y notas de Luis Alberto Sánchez. Lima: Editoral P.T.C.M., 1947.

Hugo, Victor. La Légende des Siècles. París: 1889.

Jaimes Freyre, Ricardo. Castalia bárbara [1899] Libros del Bicho 57. México: Premia Editora, 1984.

Joudra, Pierre. L'Exotisme dans la littérature française depuis Chateaubriand. París: Boivin \& Cie, Editeurs, 1938.

Kabbani, Rana. Europe's Myths of Orient. Bloomington: Indiana University Press, 1986. Masiello, Francine. Lenguaje e ideologia. Las escuelas argentinas de vanguardia. Buenos Aires: Hachette, 1986.

Paz, Octavio. Cuadrivio. Serie del volador. México: Joaquín Mortiz, 1980.

Perus, Françoise. Literatura y sociedad en América Latina: el modernismo. La Habana: Casa de las Américas, 1976.

Poesie française. Anthologie critique. Preface de Philippe Soupault. París: Borda, 1982. Rama, Ángel. Rubén Dario y el modernismo. Circunstancias socioeconómicas de un arte americano. Colección Temas 39. Caracas: Ediciones de la Biblioteca de la Universidad Central de Venezuela, 1970. 
Said, Edward. Orientalism. New York: Vintage Books, 1978.

Schwartz, William Leonard. The Imaginative Interpretation of The Far East in Modern French Literature. Paris: Librairie Ancienne Honore Champion, 1927.

Tablada, José Juan. El Florilegio. París, México: Librería de la vida de Ch. Bouret, 1904. Viñas, David. Literatura argentina y realidad politica. Biblioteca Argentina Fundamental. Serie complementaria: Sociedad y cultura. Buenos Aires: Centro Editor de América Latina, 1982. 